\title{
A Survey of English Phonetics Instruction in China
}

\author{
Zhengwei Pei ${ }^{1} \&$ Kerong Qin ${ }^{1}$ \\ ${ }^{1}$ School of Foreign Studies, Nanjing Agricultural University, Nanjing, China \\ Correspondence: Zhengwei Pei, School of Foreign Studies, Nanjing Agricultural University, 1 Weigang, \\ Nanjing, Jiangsu 210095, China. Tel: 86-025-84396600. E-mail: wei@njau.edu.cn
}

Received: July 31, 2015 Accepted: August 20, 2015 Online Published: September 29, 2015

doi:10.5539/ijel.v5n5p75 URL: http://dx.doi.org/10.5539/ijel.v5n5p75

\begin{abstract}
Although pronunciation is a salient component of effective oral communication, English phonetics instruction has long been marginalized in China and relevant research is also scarce. To bridge this gap, we did a survey of 64 English majors from a Chinese university and 13 English Phonetics quality courses on national, provincial and collegiate levels constructed from 2004 to 2014 by Chinese universities. Our survey study disclosed tertiary-level students' perceptions of English phonetics instruction and the state quo of English phonetics instruction in China. Based on the results of our study, implications for how to advance English phonetics instruction of China in the future were discussed.
\end{abstract}

Keywords: English phonetics instruction, China, English majors, quality courses, survey

\section{Introduction}

The ultimate goal of language learning is to communicate in the target language. Successful oral communication presupposes the acquisition of phonetic skills. Chen \& Hu's (2006) survey reveals that Chinese people's poor pronunciation is the major hindrance to their conversation with foreigners working in China. Therefore, intelligible pronunciation as "an essential component of communicative competence" must be viewed and taught as an integral part of oral communication (Morley, 1991, p. 488).

Given the significance of phonetics, English phonetics instruction is undoubtedly the foundation of teaching English as a foreign language (EFL). However, it has long been marginalized in Chinese classrooms, and meanwhile research on EFL phonetics and phonological acquisition is scant in China. On July 22, 2015, we searched through the articles published in nine leading foreign language journals (i.e. Foreign Language Teaching and Research, Modern Foreign Languages, Foreign Language Research, Foreign Language Learning Theory and Practice, Foreign Languages and Their Teaching, Foreign Language World, Foreign Language Education, Foreign Languages in China and Technology Enhanced Foreign Language Education) in China National Knowledge Infrastructure over the last three years with the thematic words related to English phonetics and phonology, only to find 12 relevant articles amongst approximately 3,500 articles, occupying a small proportion of the total $(0.3 \%)$. Hence, we feel an urge to research into EFL phonetics instruction for the purpose of contributing to the bridging of this gap.

Specifically, the study reported in this article addresses two research questions: 1) what are university students' perceptions of English phonetics instruction in China? 2) what is the state quo of English phonetics instruction in China? To answer these questions, we did a survey and based on its results, we first depict tertiary-level students' perceptions of English phonetics instruction, then analyze the current status of English phonetic instruction in China, and finally discuss the implications for how to advance the teaching on English phonetics in the future.

\section{Methodology}

\subsection{Survey of English Majors to Answer Question One}

Considering that tertiary-level English majors in China need to take the compulsory course English Phonetics in the first year of university study to develop their basic phonetic skills, we recruited 64 sophomore English majors from a university in Nanjing as our participants. They were aged from 18 to 22, averaging 19.5. The majority of them were females $(n=58,90.6 \%)$, reflecting a gender imbalance typical among students of language in China.

For the survey, we devised a 9-item questionnaire in Chinese, the last four of which were multiple-choice 
questions. This survey required participants to tell us how they viewed English phonetics learning and how English phonetics teaching was usually done in their class. It took about 10 minutes to complete, and was organized during regular class hours in a sound laboratory. While responding to the questionnaire, the participants were reminded to read all the items and options on it carefully and express their opinions frankly. They were also allowed to raise doubts, if necessary. At the conclusion of the survey, questionnaires were reclaimed with a full return rate. Later on, they were checked and counted as valid. For each participant, his or her responses to all the items surveyed on the questionnaire were extracted and keyed into the computer. SPSS 16.0 was then run to perform descriptive analysis.

\subsection{Survey of Quality Courses to Answer Question Two}

In 2003, the Chinese Ministry of Education launched the project of constructing national quality courses to promote classroom teaching quality at tertiary institutions. Following national steps, most provinces and universities started the same work. Nowadays, the three-layer (i.e., national, provincial, collegiate) quality courses network has been set up, acting as a role model for teachers of the same course to follow. For each quality course, the course coordinator ought to construct a curriculum website, through which the course-related materials can be uploaded for students' reference.

Our sample comprised 13 curriculum websites for English Phonetics quality courses on national $(\mathrm{n}=1)$, provincial $(n=6)$ and collegiate $(n=6)$ levels. The websites were constructed from 2004 to 2014 by course coordinators from 12 universities of China. The national and provincial courses were mainly derived from www.jingpinke.com, an open database directed by the Chinese Ministry of Education to display recourses of all the national and provincial quality courses ever constructed. The collegiate courses were taken from university websites; to pinpoint these courses, we searched for the websites of foreign language institutes, normal universities and prestigious comprehensive universities of China.

With the 13 websites logged in to, we gleaned the textual information on teaching objective, faculty, content, materials, activities, facilities, learning assessment and 49 playable teaching videos for our research. The gathered information was classified for further analysis.

\section{Results and Discussion}

\subsection{Students' Perceptions of English Phonetics Instruction}

It is known from Table 1 that nearly $70 \%$ of the participants deemed English phonetics learning very important. Roughly $88 \%$ of them thought poorly of their English pronunciation when asked to make a self-evaluation. Meanwhile, over half of the participants (53.2\%) were dissatisfied with their current pronunciation and most of them $(81.2 \%)$ desired to pronounce like English native speakers.

Although English majors attached great importance to their English phonetic competence, $53.1 \%$ of them considered that the course of English Phonetics offered by their university was not so helpful. As to which aspects of teaching content in class helped improve students' phonetic competence, the top response was liaison (51.6\%), followed by intonation (43.8\%) and rhythm (17.2\%), all of which belong to suprasegmentals. In phonetics class, the commonest activity arranged by teachers was, also a traditional way, for students to read after their teachers. Peer correction as a cooperative and relaxing teaching activity was put into use, but not frequently. With the fast development of multi-media technology, the tape recorder gradually gave way to the computer which was reported by $68.8 \%$ of the participants as the most frequently used facility by phonetics teachers. With regard to the teaching faculty, an overwhelming number of the participants $(90.6 \%)$ welcomed natives from English-speaking countries, and 31.2\% welcomed local teachers from China at the same time.

Table 1. Students' perceptions of English phonetics instruction

\begin{tabular}{|c|c|c|c|}
\hline Items & Options & Response & $\%$ age \\
\hline 1. Is English phonetics & Of no importance & 0 & 0 \\
\hline learning of importance & Of low importance & 3 & 4.7 \\
\hline \multirow[t]{2}{*}{ to you? } & Of medium importance & 17 & 26.5 \\
\hline & Of high importance & 44 & 68.8 \\
\hline \multirow{5}{*}{$\begin{array}{l}\text { 2. How is your English } \\
\text { pronunciation? }\end{array}$} & Very bad & 1 & 1.6 \\
\hline & $\mathrm{Bad}$ & 14 & 21.9 \\
\hline & Not so good & 41 & 64.1 \\
\hline & Quite good & 7 & 10.9 \\
\hline & Very good & 1 & 1.6 \\
\hline
\end{tabular}




\begin{tabular}{|c|c|c|c|}
\hline \multirow{4}{*}{$\begin{array}{l}\text { 3. Are you satisfied } \\
\text { with your } \\
\text { pronunciation? }\end{array}$} & Not satisfied at all & 6 & 9.4 \\
\hline & Not so satisfied & 28 & 43.8 \\
\hline & Somewhat satisfied & 26 & 40.6 \\
\hline & Very satisfied & 4 & 6.2 \\
\hline \multirow{5}{*}{$\begin{array}{l}\text { 4. What is your goal } \\
\text { for English } \\
\text { pronunciation? }\end{array}$} & Want to achieve native-like pronunciation & 52 & 81.2 \\
\hline & Retain pronunciation features of the Chinese & 3 & 4.7 \\
\hline & Pronounce clearly enough to be intelligible & 6 & 9.4 \\
\hline & Pass the English phonetics course exam & 2 & 3.1 \\
\hline & Have no definite goal & 1 & 1.6 \\
\hline \multirow{3}{*}{$\begin{array}{l}\text { 5. Is the English } \\
\text { phonetics course of } \\
\text { help to you? }\end{array}$} & Of little help & 34 & 53.1 \\
\hline & Of medium help & 27 & 42.2 \\
\hline & Of great help & 3 & 4.7 \\
\hline \multirow{7}{*}{$\begin{array}{l}6 . \text { Which aspects of } \\
\text { teaching content taught } \\
\text { in phonetics class help } \\
\text { you most? }\end{array}$} & Vowels & 9 & 14.1 \\
\hline & Consonants & 3 & 4.7 \\
\hline & Stress & 7 & 10.9 \\
\hline & Intonation & 28 & 43.8 \\
\hline & Rhythm & 11 & 17.2 \\
\hline & Weak form & 4 & 6.2 \\
\hline & Liaison & 33 & 51.6 \\
\hline \multirow{3}{*}{$\begin{array}{l}\text { 7. Which teaching } \\
\text { activities are organized } \\
\text { in phonetics class? }\end{array}$} & Students' reading after their teacher & 46 & 71.9 \\
\hline & Peer correction & 18 & 28.1 \\
\hline & Teachers' individual coaching and correction & 28 & 43.8 \\
\hline \multirow{4}{*}{$\begin{array}{l}\text { 8. Which teaching } \\
\text { facilities are used in } \\
\text { phonetics class? }\end{array}$} & Tape recorders & 13 & 20.3 \\
\hline & Computers for playing audio materials & 44 & 68.8 \\
\hline & Pictures used as teaching aids & 6 & 9.4 \\
\hline & Teaching software & 4 & 6.2 \\
\hline \multirow{3}{*}{$\begin{array}{l}\text { 9. Which group of } \\
\text { phonetics teachers do } \\
\text { you prefer? }\end{array}$} & Locals from China & 20 & 31.2 \\
\hline & Natives from English-speaking countries & 58 & 90.6 \\
\hline & Foreigners from non-English-speaking countries & 1 & 1.6 \\
\hline
\end{tabular}

\subsection{State Quo of English Phonetics Instruction}

By way of summarizing and comparing the information from the 13 sample qualities courses, we have gained a snapshot of current English phonetics instruction, which is to be profiled from seven aspects.

\subsubsection{Teaching Objective}

It is indicated in the sample that the course of English Phonetics is intended to improve Chinese EFL learners' English pronunciation, including correctly pronouncing individual phonemes and words as well as mastering rhythmic and intonation patterns of English. Five sample courses highlight suprasegmental teaching in terms of rhythm and intonation. Additionally, the courses all come to a consensus that phonetic competence should be fostered in combination with listening and speaking skills so that students will be able to communicate effectively in English. As early as eighteen years ago, Jones (1997, p. 111) concluded that pronunciation would, whenever possible, be taught in concert with other skills, not as a separate entity, but as another string in the communicative bow.

\subsubsection{Teaching Faculty}

All the courses are taught by local teachers in China. As reported in 3.1, English majors in our study favored being taught by English speaking natives, as they were exposed to the British and American accents, especially General American (GA) and Received Pronunciation (RP), inside and outside the English class. Actually, Chinese teachers and native English teachers are complementary to each other; the former excel at coping with segmentals, the latter good at teaching suprasegmentals, as discovered by Bao and Hou (2014) in their one-semester English pronunciation teaching experiment. Thus it is ideal to combine merits of these two types of teachers in phonetics class to achieve optimal teaching effect.

\subsubsection{Teaching Content}

The sample courses give similar teaching content on segmental and suprasegmental levels, to be specific, vowels, consonants, stress, rhythm and intonation. By counting class periods of every course (see Table 2), we found that except for one course (No. 4) which makes no mention of periods' allocation, 7 out of the 12 courses spend more time on suprasegmental teaching. 
Table 2. Allocation of periods on segmentals and suprasegmentals in sample courses

\begin{tabular}{llllll}
\hline $\begin{array}{l}\text { Course } \\
\text { No. }\end{array}$ & Segmentals & \multicolumn{3}{c}{ Suprasegmentals } & $\begin{array}{l}\text { Total } \\
\text { periods }\end{array}$ \\
\cline { 2 - 5 } class periods & \%age & class periods & \%age & 36 \\
2 & 12 & 33.3 & 16 & 44.4 & 32 \\
3 & 20 & 62.5 & 12 & 37.5 & 32 \\
4 & 10 & 31.2 & 16 & 50.0 & 32 \\
5 & $/$ & $/$ & $/$ & $/$ & 70 \\
6 & 24 & 34.3 & 34 & 48.6 & 32 \\
7 & 12 & 37.5 & 18 & 56.2 & 66 \\
8 & 40 & 60.6 & 22 & 33.3 & 30 \\
9 & 12 & 40.0 & 14 & 46.7 & 36 \\
10 & 8 & 22.2 & 20 & 55.5 & 36 \\
11 & 22 & 61.1 & 14 & 38.9 & 72 \\
12 & 36 & 50.0 & 36 & 50.0 & 64 \\
13 & 20 & 31.2 & 42 & 65.6 & 60 \\
\hline
\end{tabular}

As the core of English phonetics instruction, segmentals and suprasegmentals are closely connected with the debate on intelligibility and native-likeness. Some studies, empirical or review, demonstrate a support for balance between the two. For example, Breitkreutz, et al. (2001) surveyed instructors and program coordinators of 67 English-as-a-second-language (ESL) programs in Canada with the conclusion that many respondents supported a balanced approach to pronunciation instruction. In Korea, Kwon's (2009) review of 117 articles published from 1994 to 2008 suggests that research on segmental features of English was dominant during the 1994-1998 time period, but became more balanced with research on suprasegmentals emerging from 2004 to 2008. Studies in Iran and Bangladesh (Gilakjani, 2011; Jahan, 2011) also reveal that ESL/EFL teachers should revolve around both segmental and suprasegmental features in class. Other studies, however, seem to show a shift of focus on research priority. Following Breitkreutz, et al. (2001), Foote et al. (2011) did a similar survey with 159 instructors and program coordinators one decade later, but reported a slightly greater focus on segmentals in class. Levis \& Grant (2003) laid down the principle that pronunciation instruction should focus primarily on suprasegmentals, as mastery of them is likely to make a greater contribution to intelligibility than that of segmentals. Suprasegmentals, by virtue of their association with discourse meaning and connected speech, are more likely than segmentals to pertain directly to skills in using the spoken language. In English phonetics teaching of China, suprasegmental tendency has already been a reality, as pointed out by Cui (2010) and confirmed by the results of our study here.

\subsubsection{Teaching Materials}

The following five types of teaching materials are often used in the courses we surveyed.

1) Textbooks: 12 courses purport to use or refer to RP-oriented textbooks, either introduced as original editions or compiled by Chinese scholars themselves, e.g. Ship or Sheep? An Intermediate Pronunciation Course published by Cambridge University Press and English Pronunciation and Intonation Practice by Higher Education Press, Beijing.

2) Multimedia courseware: 10 courses mention it as one of the chief teaching materials in class and will get it uploaded to the curriculum websites shortly after class.

3) Reading materials: materials of this sort are intended for students to improve their English pronunciation on their own, consisting of English tongue twisters, poetry and texts of other classic English textbooks, etc.

4) Audio files: a number of audio files such as English songs and speeches are utilized by 9 courses.

5) Video files: all the courses make use of this type of popular materials, involving BBC/VOA news, English animations, ballads, and movie clips, to enliven their classrooms.

Teachers for 6 courses have customized teaching materials depending on students' learning problems and requirements, as it is difficult for teaching materials prepared for an international market to cater to learners with different needs, personalities, learning styles and cultural backgrounds (Jones, 1997). In one course, for instance, training handouts are particularly designed for the students speaking Fujian dialects.

Besides textbooks and courseware, the other three types are supplementary materials stemming from rich online English resources which teachers today have access to thanks to advanced technology. Online resources as a substitute for traditionally printed materials easily motivate students in their phonetics learning, change their 
reception of English phonological input and simultaneously appeal to teachers who are seeking ways to include interesting and authentic materials into their lessons. The survey by Henderson et al. (2012) in seven European countries (Finland, France, Germany, Macedonia, Poland, Spain and Switzerland) also shows that online resources are the most commonly chosen learning materials besides textbooks. Hismanoglu (2010) carried out a study on online pronunciation resources in North Cyprus, whose participants were 109 language teachers working in preparatory schools of five different universities. This study shows that young and less experienced teachers were more enthusiastic about using online pronunciation resources and found them beneficial for students' pronunciation and teachers' professional development, while those who were seniors and with more teaching experience needed training as to how to use online resources.

It is overtly seen that native accents (i.e. RP and GA) still dominate textbooks and supplementary materials. In the contexts of English as an international language or a lingua franca, English phonetics teachers and teaching materials developers of China need to incorporate accents of English varieties into textbooks and classrooms. In Finland, it is recommended that the percentage of non-native accents in the textbook should increase, and Finnish textbooks did adopt other English varieties, especially non-native accents of the outer and expanding circles, such as African, Indian, Dutch, German, Polish, French, Chinese and Finnish accents, though their amount was not in abundance (Kopperoinen, 2011), Recently, Buckingham (2015) brought up a cosmopolitan view in support of a diversity of accents in teaching materials over an emphasis on inner-circle English accents.

\subsubsection{Teaching Activities}

By examining the collected information and teaching videos, we classified six types of classroom activities: 1) the teacher gives lectures on English phonetics knowledge and skills; 2) students listen and repeat; 3) students read aloud materials including poetry, tongue twisters, speeches and essays, etc.; 4) students imitate such audio-visual materials as songs and movie clips; 5) students do listening and speaking practice in forms of describing a picture, giving a talk or discussing on a topic in pairs or groups; 6 ) the teacher or peers help correct phonetic mistakes.

The activities we have summarized also appear in English phonetics class of other countries. According to a survey by Murphy (2011) amongst 36 EFL teachers in Ireland, the most frequently selected activity was "teachers speak and learners repeat what they say", $97.2 \%$ of respondents claiming to have used it within the past three months. Turning to the participants in our study, we discovered that this activity was also the most frequently chosen one (71.9\%). Murphy stated that the activities selected as the most frequently used conflicted with those rated as the most effective, because the most effective activities rated by teachers were intonation practice. The disconnection between what phonetics teachers always do in class and which activities really work is worthy of teachers' attention.

In addition to phonetics teaching activities in class, extracurricular activities (e.g. pronunciation and intonation contest, recitation contest, movie dubbing contest, drama performance) were organized in 8 courses for students to take part in. In one course students were encouraged to volunteer for intercultural communication events, such as Beijing Olympic Games, to have their English phonetic competence tested and promoted.

\subsubsection{Teaching Facilities}

As reported in 3.1, the rapid development of multi-media technology enables the computer to replace the tape recorder as the most frequently used facility for phonetics class. This result is consistent with what we have found from the sample. The 13 courses all draw on modern technology and devices, among which multimedia system and computer-assisted software will be expounded in detail.

Ten courses mention the application of multimedia system. In Malaysia the Multimedia Pronunciation Learning Management System (MPLMS) has been created. It is a timely and useful tool to provide personalized one-to-one guidance so as to cope with the limitations of traditional pronunciation teaching in non-native English speaking countries (Por \& Fong, 2011a). Por \& Fong (2011b, 2013) further investigated the effect of MPLMS in three presentation modes, proving that it can help improve learners' sound discrimination abilities and pronunciation. The role of multimedia is also acknowledged by Chinese scholars Bu (2003) and Zhao \& Jin (2004); they discussed the superiority and feasibility of applying multimedia technology into English phonetics teaching.

About half of the courses apply computer-assisted software into class. For example, the first course runs software demonstrating how to pronounce certain phonemes in the teaching video, and the second one uses animation software to impart English phonetic knowledge and pronunciation rules. Computer-assisted software is in wide use in Computer-Assisted Pronunciation Training (CAPT). Sha (2005) thought that computer-assisted 
instruction by means of training software could facilitate suprasegmental teaching and learning. Thomson (2011) used a specially designed CAPT application and did significantly improve participants' vowel intelligibility by giving both visual and auditory feedback.

The central issue in CAPT is how to provide adequate feedback. Among the various ways to accomplish feedback, the commonest methods are visualization and through automatic speech recognition technology (Levis, 2007). At the same time, visualization is a major method that speech analysis software turns to for pronunciation training purpose, such as Better Accent Tutor (Zhuang \& Bu, 2011) and Speech Analyzer (Xie, 2007). Hincks (2003) in Sweden investigated the program Talk to Me which can provide some form of automatic feedback. Results indicate that practice with the program was of help to those who began the course with a strong accent.

It seems that more software is employed abroad, say, Karaoke, Speechant, audioblog and podcasting. Karaoke was invented in Japan and is now known to the world as linked to music. Speechant is a vowel notation system borrowing conception of music notes and is to do accent ratings for learners. Both of the software has infused technology into the classroom and has proven to be helpful in pronunciation instruction within Colombian (Rengifo, 2009)) and Portuguese (Dos Reis \& Hazan, 2012) contexts. Although its impact on foreign language teaching and learning remains to be explored, CAPT is playing a positive role in phonetics instruction; therefore, pre- and in-service teacher training in this respect is necessary.

\subsubsection{Learning Assessment}

Formative assessment and summative assessment coexist in the 13 courses. The former encompasses students' attendance records and performance in class as well as level of participation in extracurricular and intercultural activities. The latter is in forms of written (e.g. listen and discriminate minimal pairs) and oral tests (e.g. read words, sentences, passages or give a talk) at the end of the course.

Comparatively speaking, English phonetics learning assessment pays more attention to the results of final-term written and oral tests. According to Cui (2010), the desirable form of summative assessment is a combination of written and oral tests, but its validity needs to be improved. In order to construct and improve the system of English phonetics testing in higher education of China, Pei (2011) took a set of English phonetics tests as an example and elaborated its designing method, content, administration, evaluation and the procedure for its quality analysis as well.

Unlike China where a common standard has not been established to assess pronunciation, European countries can refer to the Common European Framework of Reference (CEFR). Yet, only a minority of teachers linked their assessment to this standard (Henderson, et al., 2015). For example, although a Finnish version of the CEFR assessment scale has been introduced in EFL phonetics teaching of Finland, a very small proportion of the teachers referred to this established national or international scale (Tergujeff, 2012). Therefore, there is still a long way to go towards formulating a scientific and comprehensive English phonetics assessment system and then putting it into practice.

\section{Conclusion}

Several implications for how to advance English phonetics instruction of China in the future are discussed as follows.

1) Pronunciation is a salient component of effective oral communication in English. Its value has fully been recognized by English majors of China, but its teaching is not so satisfactory in the eyes of students. Chinese teachers should pay due attention to English phonetics instruction and endeavor to promote their teaching quality.

2) Although English Phonetics quality courses take effective communication as their ultimate pedagogical goal, i.e. phonetics is not merely taught and trained for the sake of phonetics, a scientific and standard assessment system needs to be built in China to objectively measure students' English phonetic competence and progress.

3) To avoid mismatch between the activities teachers always choose in class and those really useful for students, teachers are supposed to cater for learner needs and design efficient activities, for example, suprasegmental-oriented ones in class, as suprasegmental teaching is proven to be fruitful to Chinese students.

4) Phonetics teachers and textbook compilers are advised to incorporate both native and non-native accents into their teaching materials as an embodiment of the concept of world Englishes, exposing their students to various English accents for comprehensibility during intercultural communications. Native English teachers 
can also be invited to give lectures together with Chinese teachers.

5) Pronunciation teachers and researchers at home and abroad increasingly make use of technological tools to modernize their phonetics classes, but foreign scholars have done in-depth research into CAPT. Teachers in China should study where and how computer technology and pronunciation instruction intersect to achieve better teaching effect.

\section{Acknowledgments}

This study was funded by research grants (13YYB008; 14jsyw-15) from the Humanities and Social Sciences Foundation as well as the Philosophy and Social Sciences Federation of Jiangsu Province, China.

\section{References}

Bao, L., \& Hou, G. X. (2014). An empirical study of college English pronunciation teaching by Chinese teachers and native English teachers. China Agricultural Education, (6), 74-78.

Breitkreutz, J. A., Derwing, T. M., \& Rossiter, M. J. (2001). Pronunciation teaching practices in Canada. TESL Canada Journal, 19(1), 51-61.

$\mathrm{Bu}$, Y. H. (2003). The role of modern instructional technology in the teaching of English phonetics. Technology Enhanced Foreign Language Education, (91), 52-55.

Buckingham, L. (2015). Shades of cosmopolitanism: EFL teachers' perspectives on English accents and pronunciation teaching in the Gulf. Journal of Multilingual and Multicultural Development, 36(6), 638-653. http://dx.doi.org/10.1080/01434632.2014.994638

Chen, M. L., \& Hu, X. Q. (2006). Towards the acceptability of China English at home and abroad. English Today, 22(4), 44-52. http://dx.doi.org/10.1017/S0266078406004081

Cui, X. H. (2010). A tentative plan on reconstruction of English phonetics teaching and testing system. Shandong Foreign Language Teaching Journal, (3), 64-68.

Dos Reis, J., \& Hazan, V. (2012). Speechant: a vowel notation system to teach English pronunciation. ELT Journal, 66(2), 156-165. http://dx.doi.org/10.1093/elt/ccr019

Foote, J. A., Holtby, A. K., \& Derwing, T. M. (2011). Survey of the teaching of pronunciation in adult ESL programs in Canada, 2010. TESL Canada Journal, 29(1), 1-22.

Gilakjani, A. P. (2011). A study on the situation of pronunciation instruction in ESL/EFL classrooms. Journal of Studies in Education, 1(1), 1-15. http://dx.doi.org/10.5296/jse.v1i1.924

Henderson, A. et al. (2012). The English pronunciation teaching in Europe survey: selected results. Research in Language, 10(1), 5-27. http://dx.doi.org/10.2478/v10015-011-0047-4

Henderson, A. et al. (2015). English pronunciation teaching in Europe survey: factors inside and outside the classroom. Retrieved from http://www.researchgate.net/profile/Alice_Henderson

Hincks, R. (2003). Speech technologies for pronunciation feedback and evaluation. ReCALL, 15(1), 3-20. http://dx.doi.org/10.1017/S0958344003000211

Hismanoglu, M. (2010). Online pronunciation resources: hobbies or fobbies of EFL teachers? International Journal on New Trends in Education and Their Implications, 1(2), 33-45.

Jahan, N. (2011). Teaching and learning pronunciation in ESL/EFL classes of Bangladesh. Journal of Education and Practice, 2(3), 36-45.

Jones, R. H. (1997). Beyond "listen and repeat": pronunciation teaching materials and theories of second language acquisition. System, 25(1), 103-112. http://dx.doi.org/10.1016/S0346-251X(96)00064-4

Kopperoinen, A. (2011). Accents of English as a lingua franca: a study of Finnish textbooks. International Journal of Applied Linguistics, 21(1), 71-93. http://dx.doi.org/10.1111/j.1473-4192.2010.00263.x

Kwon, B. Y. (2009). Bridging the gap between research in linguistics and English teaching pedagogy: focusing on English pronunciation education. 말소리와 옹성과학, 1(4), 73-84.

Levis, J. (2007). Computer technology in teaching and researching pronunciation. Annual Review of Applied Linguistics, 27, 184-202. http://dx.doi.org/10.1017/S0267190508070098

Levis, J. M., \& Grant, L. (2003). Integrating pronunciation into ESL/EFL classrooms. TESOL Journal, 12(2), 13-19. 
Morley, J. (1991). Pronunciation component in teaching English to speakers of other languages. TESOL Quarterly, 25(3), 481-520.

Murphy, D. (2011). An investigation of English pronunciation teaching in Ireland. English Today, 27(4), 10-18. http://dx.doi.org/10.1017/S0266078411000484

Pei, Z. W. (2011). The design of college English phonological tests and analysis of their quality. China Agricultural Education, (5), 68-72.

Por, F. P., \& Fong, S. F. (2011a). Towards transformation: the power of phonetic symbols embedded in the multimedia learning management system. English Language Teaching, 4(1), 167-173. http://dx.doi.org/10.5539/elt.v4n1p167

Por, F. P., \& Fong, S. F. (2011b). Exploring the innovative Multimedia Pronunciation Learning Managements System on students with different psychological profiles. International Journal of Business and Social Science, 2(24), 244-250.

Por, F. P., \& Fong, S. F. (2013). The use of mouth movement video and digitised phonetic symbols on pronunciation learning among learners with different psychological profiles. International Journal of Academic Research in Business and Social Sciences, 3(2), 289-297.

Rengifo, A. R. (2009). Improving pronunciation through the use of karaoke in an adult English class. Profile, 11(1), 91-105.

Sha, G. Q. (2005). Computer-assisted instruction and testing of pronunciation: a critical view. Technology Enhanced Foreign Language Education, (104), 67-71.

Tergujeff, E. (2012). English pronunciation teaching: four case studies from Finland. Journal of Language Teaching and Research, 3(4), 599-607. http://dx.doi.org/10.4304/jltr.3.4.599-607

Thomson, R. I. (2011). Computer assisted pronunciation training: targeting second language vowel perception improves pronunciation. CALICO Journal, 28(3), 744-765. http://dx.doi.org/10.11139/cj.28.3.744-765

Xie, P. (2007). Application of Speech Analyzer to English pronunciation teaching. Technology Enhanced Foreign Language Education, (118), 26-29.

Zhao, Y. S., \& Jin, P. S. (2004). Attempts to English phonetic teaching of English majors. Technology Enhanced Foreign Language Education, (97), 55-57.

Zhuang, M. Q., \& Bu, Y. H. (2011). The study of Better Accent Tutor \& visualized suprasegmental teaching. Technology Enhanced Foreign Language Education, (138), 31-38.

\section{Copyrights}

Copyright for this article is retained by the author(s), with first publication rights granted to the journal.

This is an open-access article distributed under the terms and conditions of the Creative Commons Attribution license (http://creativecommons.org/licenses/by/3.0/). 